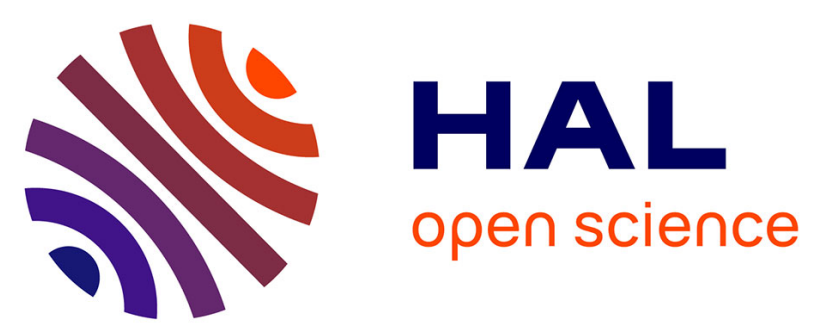

\title{
ZnO Nanowires as a Promotor of High Photo-Induced Efficiency and Voltage Gain for Cathode Battery Recharging
}

Laureline Lecarme, Vincent Consonni, Frédéric Lafolet, Thomas Cossuet, Michel Mermoux, Frédéric Sauvage, Ali Nourdine, Fannie Alloin, Jean-Claude

Leprêtre

\section{To cite this version:}

Laureline Lecarme, Vincent Consonni, Frédéric Lafolet, Thomas Cossuet, Michel Mermoux, et al.. ZnO Nanowires as a Promotor of High Photo-Induced Efficiency and Voltage Gain for Cathode Battery Recharging. ACS Applied Energy Materials, 2019, 2 (9), pp.6254-6262. 10.1021/acsaem.9b00783 . hal-02174618

\section{HAL Id: hal-02174618 https://hal.science/hal-02174618}

Submitted on 26 Nov 2020

HAL is a multi-disciplinary open access archive for the deposit and dissemination of scientific research documents, whether they are published or not. The documents may come from teaching and research institutions in France or abroad, or from public or private research centers.
L'archive ouverte pluridisciplinaire HAL, est destinée au dépôt et à la diffusion de documents scientifiques de niveau recherche, publiés ou non, émanant des établissements d'enseignement et de recherche français ou étrangers, des laboratoires publics ou privés. 


\section{ZnO Nanowires as a Promotor of High Photo-Induced}

\section{Efficiency and Voltage Gain for Cathode Battery}

\section{Recharging}

Lauréline Lecarme, ${ }^{\dagger, \ldots}$ Vincent Consonni, ${ }^{*}$ Frédéric Lafolet, $\$$ Thomas Cossuet, ${ }^{\star}$ Michel Mermoux,,$^{\dagger}$ Frédéric Sauvage, ${ }^{\phi}$ Ali Nourdine, ${ }^{\dagger}$ Fannie Alloin ${ }^{\dagger,+}$ Jean-Claude Leprêtre ${ }^{\dagger, \neq, *}$

† Univ. Grenoble Alpes, Univ. Savoie Mont Blanc, CNRS, Grenoble INP, LEPMI, 38000

Grenoble, France, Institute of Engineering Univ. Grenoble Alpes

† Univ. Grenoble Alpes, CNRS, Grenoble INP, LMGP, F-38000 Grenoble, France

$\S$ Université Paris Diderot, Sorbonne Paris Cité, ITODYS, UMR 7086 CNRS, 15 rue Jean-Antoine de Baïf, 75205 Paris Cedex 13, France

$\Phi$ Laboratoire de Réactivité et Chimie des Solides, Université de Picardie Jules Verne (UPJV), CNRS UMR 7314, 33 rue Saint Leu, 80039, Amiens, France

$¥$ Réseau sur le Stockage Electrochimique de l’Energie (RS2E), CNRS, FR3459, 80039 Amiens Cedex, France

* E-mail: Jean-Claude.Lepretre@lepmi.grenoble-inp.fr 


\section{ABSTRACT.}

In recent years, intensive efforts are focused to the conversion and the storage of the solar energy in a single device. In this work, we report the use of $\mathrm{ZnO}$-based electrodes in the form of monolayer or nanowires as a light inducer for battery recharging. Two transition metal complexes of ruthenium(II) and iron(II) are grafted onto the ZnO-based electrode in order to tune the efficiency of the system. We explore the influence of both the $\mathrm{ZnO}$ morphology and nature of the transition metal complex on the light induced voltage and faradaic efficiency towards electrochemical storage. The resulting $\mathrm{ZnO}$-based electrodes have all been found to be electrochemically photoactive and their functionalized $\mathrm{ZnO}$ nanowire counterpart has shown the best results. Once the ruthenium complex has been grafted, a high potential gain between dark and illumination conditions of $1.3 \mathrm{~V}$ is reached, which is associated with a modest faradaic efficiency of $50 \%$. However, in the presence of the iron complex, a favorable potential gain of $700 \mathrm{mV}$ is obtained and advantageously combined with a faradic efficiency of $100 \%$. These results undoubtedly highlight the remarkable synergy between photo-active $\mathrm{ZnO}$, especially in the form of nanowires, and a redox center allowing to be applied for a photo-rechargeable battery device.

KEYWORDS. Nano-architectured ZnO-linked-transition metal, Photoactive electrodes, Photoassisted charging, $\mathrm{ZnO}$ redox complex synergy, Coordination complexes.

INTRODUCTION. One of the greatest technological challenges of the $21^{\text {st }}$ century is the storage of green and renewable energy resources at a global scale. In this context, the design of a dedicated device that is simultaneously a solar energy convertor and a battery has emerged as highly promising for energy storage. ${ }^{1,2}$ Lithium-ion batteries (LIB) are of great interest for these 
stationary applications owing to their high energy density and low self-discharge. ${ }^{3}$ Consequently, a major challenge lies in the development of integrated devices to directly associate light energy conversion with LIB technology within a photo-assisted approach. ${ }^{4}$

This new concept, which involves the storage of electrochemical energy through redox photoassisted process, aims to tune the potential of an electrode at a lower energy cost for the integrated system. However, until now, only few articles have reported photo-assisted rechargeable batteries based on photo-redox sensitizer. ${ }^{5-7}$ In 2017 , Godet-Bar et al. ${ }^{6}$ were able, during photo-charging, to obtain a photo-induced voltage gain of the cell of $770 \mathrm{mV}$, as inferred from the difference between the potentials under illumination and dark, using a photo-electrode composed of boron dipyrromethene based polymer (BODIPY). In the same year, Paolella et al. ${ }^{7}$ proposed a twoelectrode system-based LIB through the direct oxidation of $\mathrm{LiFePO}_{4}$ by the photo-activation of ruthenium polypyridyl N719 dye under illumination. A gain of $150 \mathrm{mV}$ was reached as the photocharging of the LIB at the open circuit voltage proceeded.

For efficient photo-assisted rechargeable LIBs, both maximal photon absorption and trapping in the optimal range of the incident light are required. In that respect, semiconductor nanostructures including nanowires (NWs) are of high prospective materials. ${ }^{8,9}$ Owing to its high surface over volume ratio at nanoscale dimensions and its high crystallinity, semiconductor NWs can efficiently trap the light through the generation of Fabry-Perot resonances, optically guided modes or radiated modes for instance, ${ }^{10,11}$ while acting as an efficient electron transporting materials. ${ }^{12}$ In principle, they constitute a promising building block and thus an ideal candidate for photo-assisted rechargeable battery, but surprisingly, they have never been involved in such strategy so far. As a biocompatible semiconductor composed of abundant elements, $\mathrm{ZnO}$ has received an increasing interest for its integration into a variety of nanoscale engineering devices. ${ }^{13,14}$ It can further be 
grown with the shape of NWs by the low-cost, low-temperature chemical bath deposition (CBD) technique, offering a great versatility for the formation of these nano-objects on many types substrates. ${ }^{15}$

In this work, we report the first example of the photo-activity of two types of ZnO-based substrates that are functionalized with redox complexes in a battery configuration (i.e., in carbonates-based solvent using Li anode electrode). The aim of this proof-of-concept is to highlight that, by taking the benefit of the photo-induced oxidizing character of $\mathrm{ZnO}$, it is possible to modulate the photovoltage gain by $\mathrm{ZnO}$ functionalisation with an appropriate redox metal. Owing to its significant high photo-sensitivity potential (as shown in Scheme 1), ${ }^{16} \mathrm{ZnO}$ is a powerful oxidant under

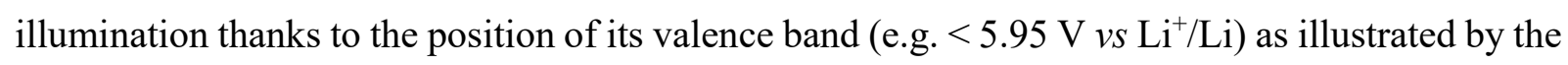
numerous publications dedicated to the photo-degradation of organic material involving $\mathrm{ZnO} .{ }^{17} \mathrm{In}$ addition, as a result from its particular oxidizing character, its use as a redox material in battery configuration cannot be involved solely, since its potential is significantly higher than the limit in stability of the conventional carbonate-based electrolyte $\left(4.2-4.5 \mathrm{~V} v s \mathrm{Li} / \mathrm{Li}^{+}\right) .{ }^{18}$ Here, we use two different transition metal complexes $(\mathrm{M})$ to tune the oxidizing character of the functionalized substrate. The main idea is to reach the threshold potential (e.g. $<4.2 \mathrm{~V} v s \mathrm{Li}^{+} / \mathrm{Li}$ ) to prevent any contribution of deleterious oxidation of the electrolyte and the benefit of the photosensitive character of $\mathrm{ZnO}$ to store electrochemical energy at lower energetic cost. In this context, once the photo-excited form of $\mathrm{ZnO}\left(\mathrm{ZnO}\left(\mathrm{e}^{-}, \mathrm{h}^{+}\right)\right)$has been generated, its oxidized form $\left(\mathrm{ZnO}_{\text {ox }}\right)$ can be easily induced by applying an anodic current ( $\mathrm{I}>0$ ) (equation 1$)$. In the present case, since it required low wavelength $(350 \mathrm{~nm})$, the potential involved to perform this oxidation step should be


respectively). 


$$
\begin{aligned}
& \mathrm{ZnO} \stackrel{\mathrm{h} v}{\longrightarrow} \mathrm{ZnO}\left(\mathrm{e}^{-}, \mathrm{h}^{+}\right) \stackrel{\mathrm{I}>0}{\longrightarrow} \mathrm{ZnO}_{\mathrm{ox}}+\mathrm{e}^{-} \\
& \mathrm{M}_{\mathrm{red}}+\mathrm{ZnO}_{\mathrm{ox}} \longrightarrow \mathrm{M}_{\mathrm{ox}}+\mathrm{ZnO} \\
& \mathrm{M}_{\mathrm{ox}} \longrightarrow \mathrm{I<0} \longrightarrow \mathrm{M}_{\mathrm{red}}
\end{aligned}
$$

However, as previously mentioned, $\mathrm{ZnO}_{\mathrm{ox}}$ exhibits a too high oxidizing character to be used as electrochemical energy storage unit. This issue can be solved, using an adapted reversible redox couple $\left(\mathrm{Mox}_{\mathrm{ox}} / \mathrm{Mred}_{\mathrm{r}}\right)$ whose potential has to be lower than the one of the stability limit of the electrolyte, leading to the photo-electro generated $\mathrm{M}_{\mathrm{ox}}$ and restoring the initial form of $\mathrm{ZnO}$ (equation 2). In a final step, without illumination (equation 3), the electrochemical energy could be affordable by applying a cathodic current allowing to retrieve $\mathrm{M}_{\mathrm{red}}$ (at a potential close to the corresponding $\left.\mathrm{E}^{\circ} \mathrm{M}_{\mathrm{red}} / \mathrm{M}_{\mathrm{ox}}\right)$. Taking into account this mechanism and in order to reach a high energetic gain, the second step is crucial to obtain the best efficiency. This electron quenching could be in competition with a side reaction involving the high reactivity of $\mathrm{ZnO}_{\text {ox }}$ (i.e. irreversible electrolyte oxidation). In addition, the oxidation of the $\mathrm{M}_{\mathrm{red}}$ has to be performed in a potential range allowing to preserve the stability of the two redox forms and to reach the higher energy storage as possible ( $\mathrm{E}^{\circ}$ up to $4.2 \mathrm{~V} v s \mathrm{Li}^{+} / \mathrm{Li}$ ) (Scheme 1). In these conditions, the efficiency of this overall mechanism deals with different criteria: i) an efficient $\mathrm{ZnO}$ photo-excitation, ii) a highly controlled electrochemically formation of $\mathrm{ZnO}_{\mathrm{ox}}$, and iii) a strong affinity between $\mathrm{ZnO}_{\mathrm{ox}}$ and $\mathrm{M}_{\mathrm{red}}$ allowing to efficiently produce its oxidized form $\left(\mathrm{M}_{\mathrm{ox}}\right)$. In this context, we propose transition metal complexes based on $3 \mathrm{~d}$ iron (II) and ruthenium (II) involving polypyridyl ligands. ${ }^{19,20}$ These complexes have been chosen because both their recognized reversible electrochemical behaviour and their oxidation potentials $\left(\mathrm{E}^{\circ}\right)$ are compatible with the electrolyte stability. 


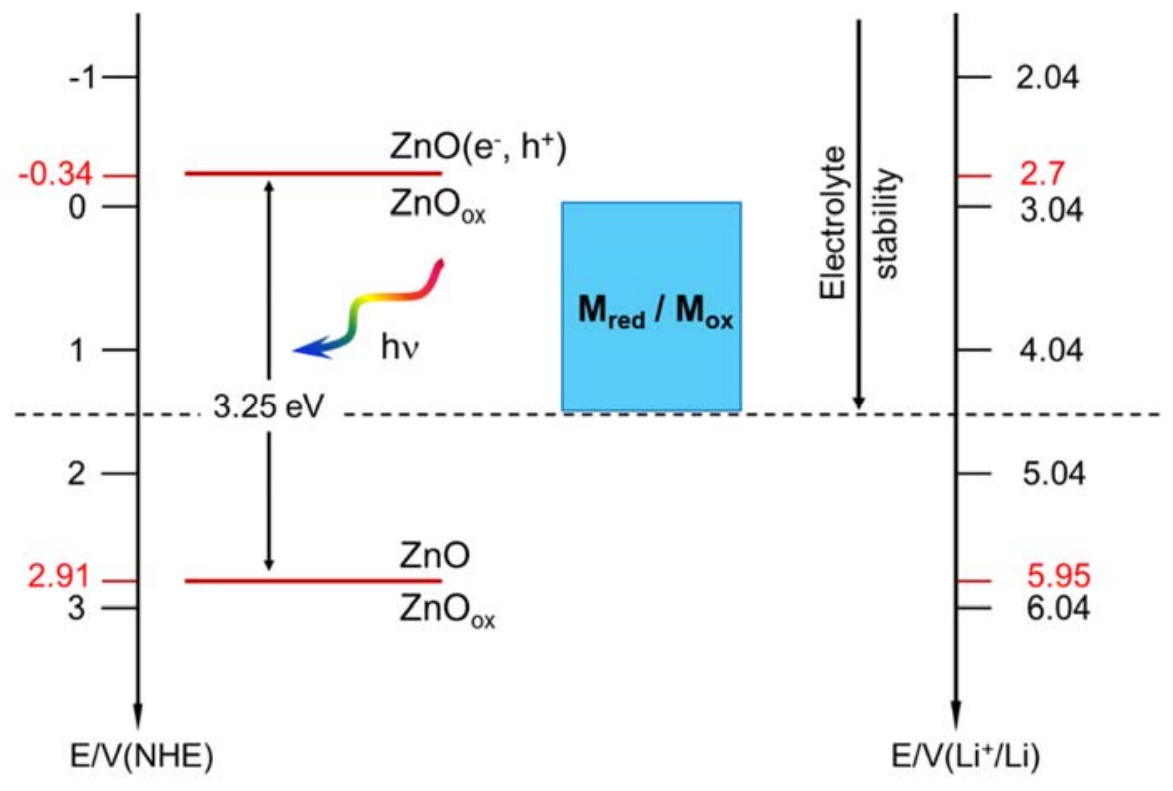

Scheme 1. Energy diagram of materials investigated.

In order to ensure an efficient covalent coupling between the $\mathrm{ZnO}$ substrate and transition metal complexes, we choose to involve ligand bearing a phenyl- $\mathrm{NH}_{2}$ functions which, in the presence of nitrite, can easily generate the diazonium derivatives. Then, by a cathodic process, the complexes can be efficiently grafted onto the surface of the $\mathrm{ZnO}$ (Scheme S1). ${ }^{21-23}$ This process allows a perfect thickness control of the deposited layer, especially those based on coordination complexes. ${ }^{24,25}$ For the sake of clarity, $\mathrm{ZnOm}$ and $\mathrm{ZnOnw}$ are used in the following to stand for $\mathrm{ZnO}$ monolayer and $\mathrm{ZnO}$ NWs, respectively, and functionalized $\mathrm{ZnOm}$ and $\mathrm{ZnOnw}$ are presented as $\mathrm{ZnOm} / \mathrm{M}^{\mathrm{II}}$ and $\mathrm{ZnOnw} / \mathrm{M}^{\mathrm{II}}$ with $\mathrm{M}=\mathrm{Fe}$ or $\mathrm{Ru}$.

\section{RESULTS AND DISCUSSION.}

\section{Electrode functionalization.}

The electroreduction of the in situ chemically generated diazonium performed on $\left[\mathrm{Fe}\left(\mathrm{tpy}-\mathrm{NH}_{2}\right)_{2}\right]^{2+}$ and $\left[\mathrm{Ru}(\text { bpy })_{2}\left(\mathrm{bpyNH}_{2}\right)\right]^{2+}$ is schematically represented in Figure 1. In both cases, the electrografting is performed in acetonitrile on the substrate by cyclic voltammetry and consist in 
50 cycles between $1.1 \mathrm{~V}$ and $-1.0 \mathrm{~V}$ vs $\mathrm{Ag}^{+} / \mathrm{Ag}$ (Figure S1). The signal amplitude is more pronounced with $\mathrm{Fe}^{\mathrm{II}}$ due to the presence of two diazonium moieties helping a better electrofunctionalization of the electrode with respect to the $\mathrm{Ru}^{\mathrm{II}}$ complex which exhibits only one $\mathrm{NH}_{2}$ function. This method permits a conformal grafting and the stacking of molecular monolayers of grafted complexes into the substrate. This is monitored by UV-visible spectroscopy from the absorbance spectra of the $\mathrm{Fe}^{\mathrm{II}}$ and $\mathrm{Ru}^{\mathrm{II}}$ complexes grafted, which exhibit characteristic peaks at $465 \mathrm{~nm}$ and $580 \mathrm{~nm}$, respectively (Figure S2a). The absorbance capability of the film can be controlled by the number of cycles (Figure S2b). Given that the amount of grafted complexes follows a linear relationship according to the number of scans, this indicates that the presence of the grafted transition metal complexes does not impact the efficiency of the electro-induced modification of the electrode.

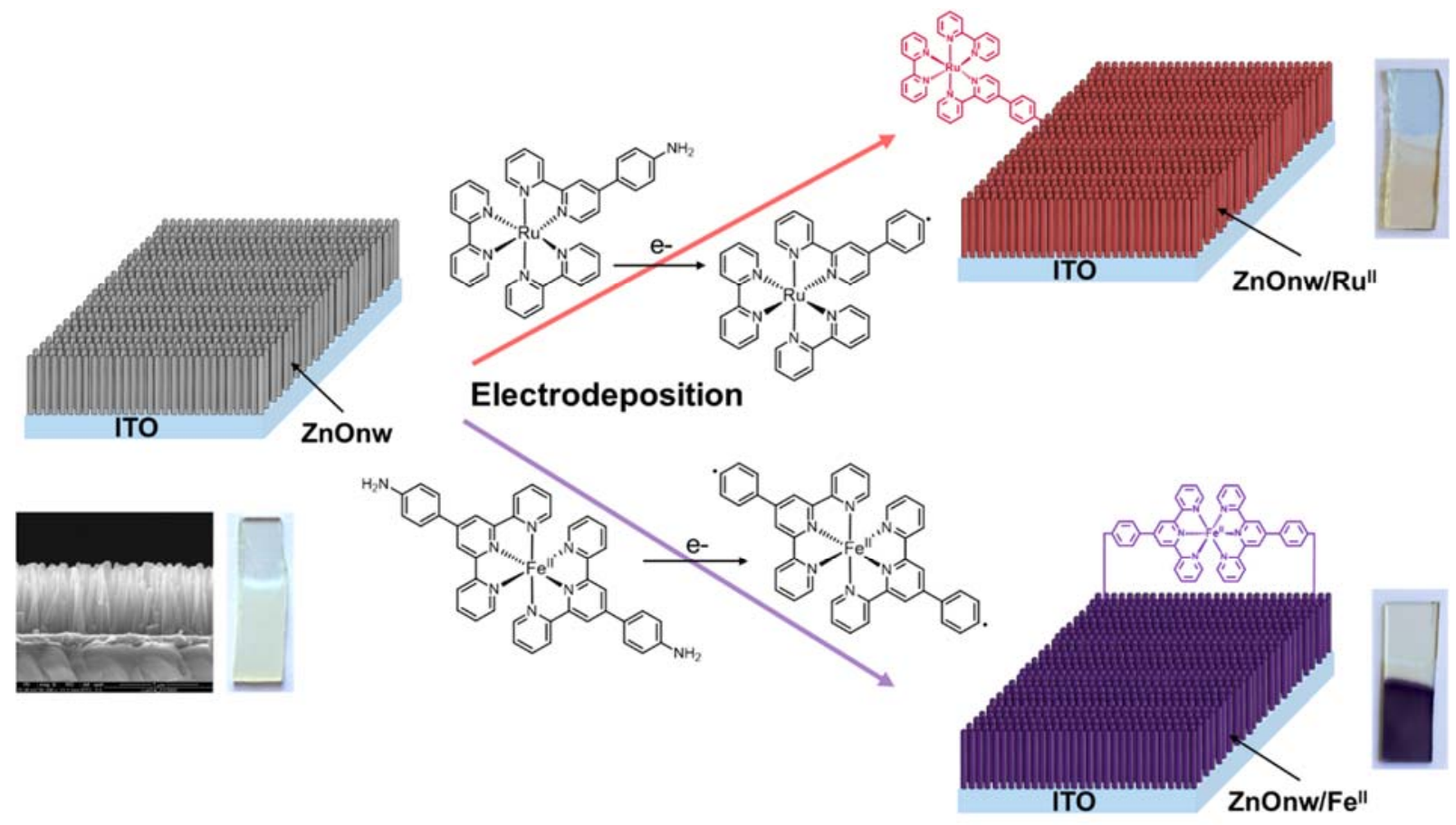


Figure 1. Schematic of the transition metal complexes electrodeposition procedure onto ITO/ZnOnw-based electrodes. The inserts are pictures of $\mathrm{ZnOnw}, \mathrm{ZnOnw} / \mathrm{Ru}^{\mathrm{II}}$ and $\mathrm{ZnOnw} / \mathrm{Fe}^{\mathrm{II}}$ electrodes with a crosssectional view SEM image of an ITO/ZnOnw-based substrate.

The cyclic voltammogram of $\mathrm{ZnOm} / \mathrm{Fe}^{\mathrm{II}}$ electrodes in the electrolyte at different scan rates is presented in Figure 2a and shows the expected reversible oxidation wave at $\mathrm{E}_{1 / 2}=3.95 \mathrm{~V} v \mathrm{~s}$. $\mathrm{Li}^{+} / \mathrm{Li}\left(\mathrm{E}_{1 / 2}=3.83 \mathrm{~V}\right.$ for $\left[\mathrm{Fe}\left(\text { tpy- }-\mathrm{NH}_{2}\right)_{2}\right]^{2+}$ in solution). The same trend arises from $\mathrm{ZnOm} / \mathrm{Ru}^{\mathrm{II}}$ electrode with a reversible electrochemical response at $\mathrm{E}_{1 / 2}=4.15 \mathrm{~V} v s . \mathrm{Li}^{+} / \mathrm{Li}\left(\mathrm{E}_{1 / 2}=4.04 \mathrm{~V}\right.$ for $\left[\mathrm{Ru}(\mathrm{bpy})_{2}\left(\mathrm{bpyNH}_{2}\right)\right]^{2+}$ in solution) (Figure $\left.2 \mathbf{b}\right)$. One can observe that, after grafting, the $\mathrm{E}_{1 / 2}$ of both systems shifted towards more positive potential. This shift is the signature of the efficient functionalization. Indeed, since the $\mathrm{NH}_{2}$ function has been removed through the electrochemical process, its donor effect is lost, leading to an increase of the $E_{1 / 2}$ value. The reversible electrochemical response is preserved regardless of the electrode (i.e. substrates) whereas the electro-functionalized electrode is electrochemically stable upon cycling after transfer in carbonate based electrolyte. Raman spectroscopy was used to confirm the successful grafting of $\mathrm{Fe}^{\mathrm{II}}$ and $\mathrm{Ru}^{\mathrm{II}}$ complexes on the electrodes. The Raman spectra recorded in the $950-1700 \mathrm{~cm}^{-1}$ wavenumber range show the dominant strong bands at about 1612, 1565, 1540,1472, 1362, and $1290 \mathrm{~cm}^{-1}$ corresponding to $\left[\mathrm{Fe}\left(\text { tpy- } \mathrm{NH}_{2}\right)_{2}\right]^{2+}$ complex as presented in Figure 2c (i.e., red solid line) and at $1606,1565,1489,1334$ and $1319 \mathrm{~cm}^{-1}$ for $\left[\mathrm{Ru}(\mathrm{bpy})_{2}\left(\mathrm{bpyNH}_{2}\right)\right]^{2+}$ complex as presented in Figure 2d (i.e., red solid line). These Raman bands are attributed to the stretching of $\mathrm{C}=\mathrm{C}$ and $\mathrm{C}=\mathrm{N}$ bonds of the pyridine rings. ${ }^{24,26-28}$

After electrodeposition of 50 cycles, the Raman spectrum of $\mathrm{ZnOnw} / \mathrm{Fe}^{\mathrm{II}}$ electrodes as revealed in Figure 2c (i.e., black solid line) shows the specific features of the metal complex. The disappearance of the band at $1598 \mathrm{~cm}^{-1}$ and a decrease in the intensity of both bands at 1485 and $1290 \mathrm{~cm}^{-1}$ confirms the covalent bonding between the $\mathrm{Fe}^{\mathrm{II}}$ complex and $\mathrm{ZnOnw}$ surface via the 
ligand. After electrodeposition, the Raman spectrum of $\mathrm{ZnOnw} / \mathrm{Ru}^{\mathrm{II}}$ electrodes is also maintained. It exhibits two additional broad bands at around 1530 and $1095 \mathrm{~cm}^{-1}$ as showed in Figure 2d. The band at $1095 \mathrm{~cm}^{-1}$ is assigned to the second-order modes of wurtzite $\mathrm{ZnO}$ and hence is typical of $\mathrm{ZnO}$ NWs. ${ }^{29}$ The band at $1530 \mathrm{~cm}^{-1}$ may be due to the formation of $\mathrm{Zn}-\mathrm{H}$ bonds on the surface of $\mathrm{ZnO} N W s^{30}$ The fact that no clear signature of wurtzite $\mathrm{ZnO}$ occurs in the case of $\mathrm{ZnOnw} / \mathrm{Fe}^{\mathrm{II}}$ electrode can be explained by its better coverage with the $\mathrm{Fe}^{\mathrm{II}}$ complex, since it presents two amine functions (and thus diazonium ones) as compared to only one amine function for the $\mathrm{Ru}^{\mathrm{II}}$ one.

(a)

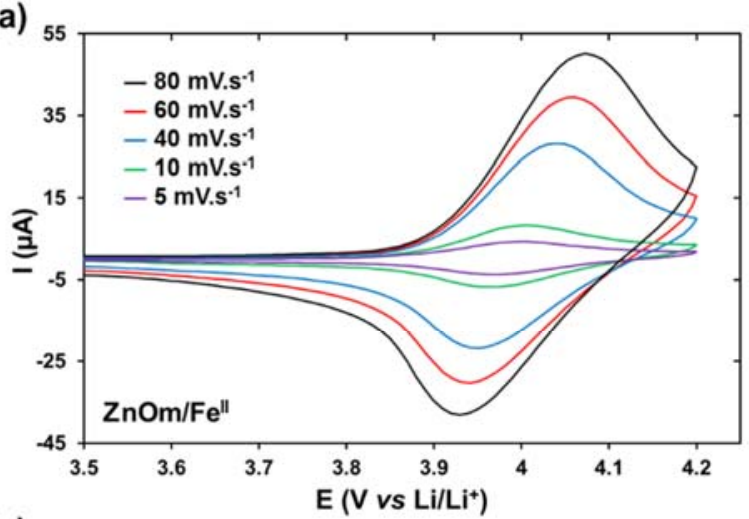

(c)



(b)

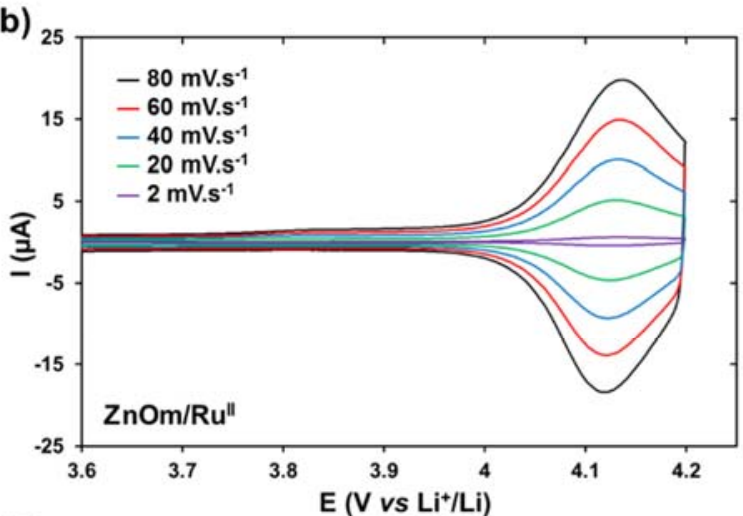

(d)

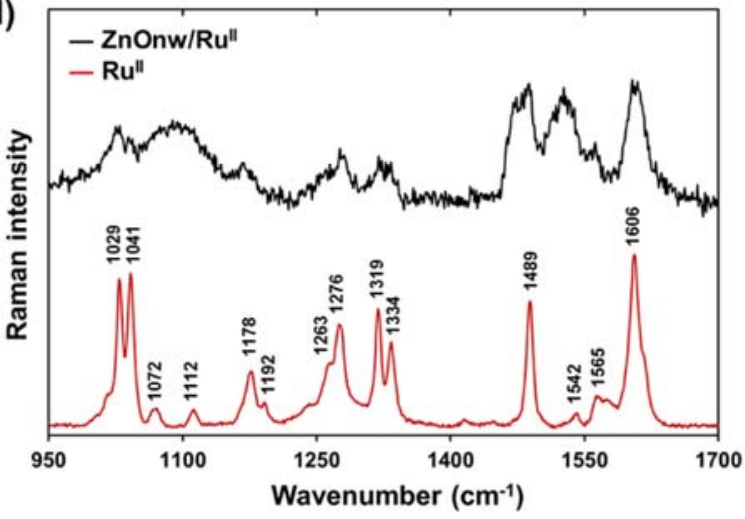

Figure 2. Cyclic voltammogram at different scan rates in $1 \mathrm{M}$ LiTFSI in EC/DMC (1/1) electrolyte of (a) $\mathrm{ZnOm} / \mathrm{Fe}^{\mathrm{II}}$ electrode and (b) $\mathrm{ZnOm} / \mathrm{Fe}^{\mathrm{II}}$ electrode. Resonance Raman spectra of (c) $\left[\mathrm{Fe}\left(\text { tpy- }-\mathrm{NH}_{2}\right)_{2}\right]^{2+}$ powder (red) and $\mathrm{ZnOnw} / \mathrm{Fe}^{\mathrm{II}}$ electrodes (black) and (d) $\left[\mathrm{Ru}(\mathrm{bpy})_{2}\left(\mathrm{bpyNH}_{2}\right)\right]^{2+}$ powder (red) and $\mathrm{ZnOnw} / \mathrm{Ru}^{\mathrm{II}}$ (black). 


\section{Photo-electrochemical study with bare $\mathrm{ZnO}$ electrodes.}

As described by C. Zoski, ${ }^{16} \mathrm{ZnO}$ possesses a high photo-activity in the range of $3.5-6 \mathrm{~V} v s \mathrm{Li}^{+} / \mathrm{Li}$. Accordingly, in order to estimate the photo-assisted effect during the charging, $\mathrm{ZnOm}$ and $\mathrm{ZnOnw}$ morphologies were tested under illumination in Li battery configuration whereas the faradaic efficiency $(\mathrm{FE})$ was estimated by the faradaic ratio between the charge and discharge which were performed by fixing a given current ( $\mathrm{I}>0$ for the charge under illumination, $\mathrm{I}<0$ in darkness for the discharge). Table 1 presents the difference in the potential values under dark and illumination conditions for the charge $\left(\Delta \mathrm{E}_{\text {light/dark }}\right)$ and the $\mathrm{FE}$ with and without light at different values of applied current (I) for the $\mathrm{ZnOm}$ and $\mathrm{ZnOnw}$ surfaces. Galvanostatic measurements show a good cyclability and reproducibility for all samples, as shown in Figure 3a in the case of ZnOnw.

Table 1. Electrochemical data of $\mathrm{ZnOm}$ and $\mathrm{ZnOnw}$ as a function of the applied current (I). $\mathrm{x}$ indicates that no value is reported because the potential limit $\left(\mathrm{E}_{\text {limit }}\right)$ of $4.2 \mathrm{~V} \mathrm{vs} \mathrm{Li}^{+} / \mathrm{Li}$ was immediately reached.

\begin{tabular}{ccccccc}
\hline $\mathbf{I}(\boldsymbol{\mu A})$ & \multicolumn{2}{c}{$\boldsymbol{\Delta} \mathbf{E}_{\text {light/dark }}(\mathbf{m V})$} & \multicolumn{2}{c}{$\mathbf{F E}$ under dark (\%) } & \multicolumn{2}{c}{ FE under light (\%) } \\
\hline 1 & $\mathrm{ZnOm}$ & $\mathrm{ZnOnw}$ & $\mathrm{ZnOm}$ & $\mathrm{ZnOnw}$ & $\mathrm{ZnOm}$ & $\mathrm{ZnOnw}$ \\
1.5 & 560 & 70 & 99 & 100 & 50 & 80 \\
2 & 920 & 110 & 95 & 100 & 40 & 75 \\
2.5 & $\mathrm{x}$ & 190 & $\mathrm{x}$ & 99 & $\mathrm{x}$ & 62 \\
3 & $\mathrm{x}$ & 340 & $\mathrm{x}$ & 99 & $\mathrm{x}$ & 59 \\
3.5 & $\mathrm{x}$ & 560 & $\mathrm{x}$ & 98 & $\mathrm{x}$ & 57 \\
& $\mathrm{x}$ & 900 & $\mathrm{x}$ & 98 & $\mathrm{x}$ & 56 \\
\hline
\end{tabular}


Scheme 2 shows the possible photo-electrochemical oxidation reaction mechanisms during the photo-charging.

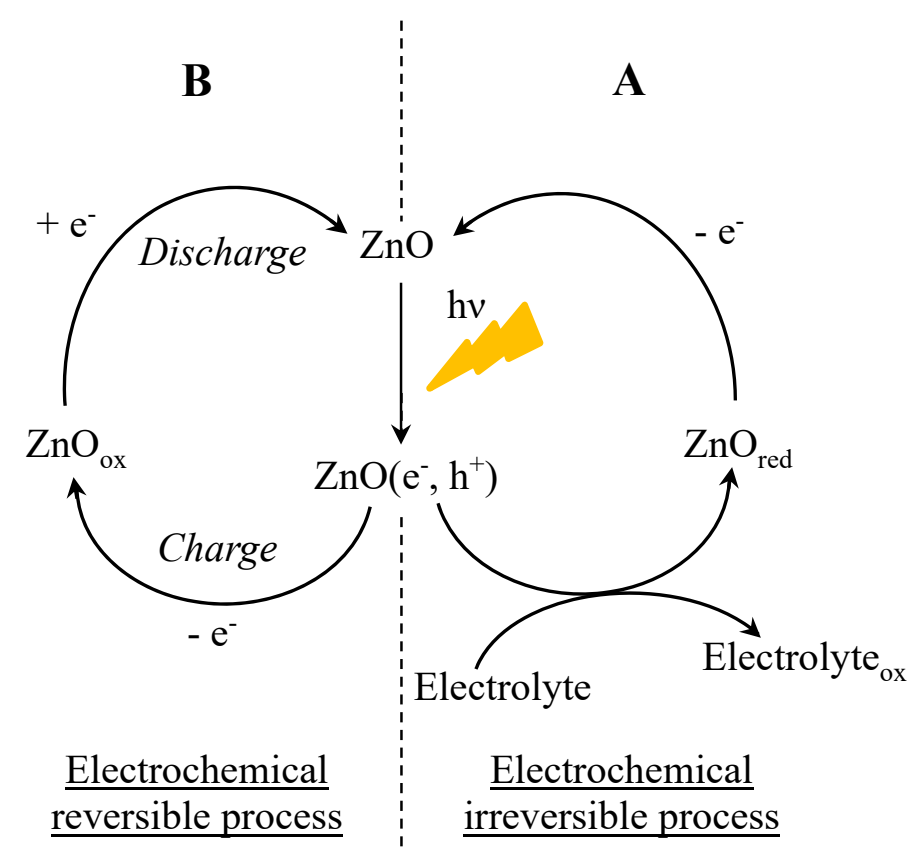

Scheme 2. Different possible photo-electrochemical oxidation pathways involving $\mathrm{ZnO}$ during the photocharging processes.

Under illumination, the deactivation of $\mathrm{ZnO}\left(\mathrm{e}^{-}, \mathrm{h}^{+}\right)$can follow two antagonist pathways. For pathway $\mathbf{A}, \mathrm{ZnO}\left(\mathrm{e}^{-}, \mathrm{h}^{+}\right)$can directly oxidizes the electrolyte by hole transfer owing to the strong oxidizing character of its valence band. This typically leads to the reduced form of $\mathrm{ZnO}$ which can regenerate initial $\mathrm{ZnO}$ by a cathodic/galvanic process. This photo-induced reaction does not allow to store any electrochemical energy. For pathway $\mathbf{B}$, where electrochemical energy is stored since $\mathrm{ZnO}\left(\mathrm{e}^{-}, \mathrm{h}^{+}\right)$is easier oxidized, an anodic process leads to $\mathrm{ZnO}_{\text {ox }}$ (charging process) followed by $\mathrm{ZnO}$ regeneration by subsequent electrochemical reduction (discharge). Knowing that the

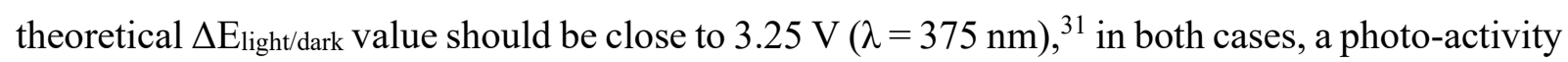
is revealed with a maximal $\Delta$ Elight/dark value of $920 \mathrm{mV}$ and $900 \mathrm{mV}$ for $\mathrm{ZnOm}$ and $\mathrm{ZnOnw}$, respectively. In the case of $\mathrm{ZnOm}$, a jump of $\Delta$ Elight/dark for a small applied current is shown in 
Figure 3b (i.e., green solid line). However, beyond $1.5 \mu \mathrm{A}$, the potential limit (Elimit) of $4.2 \mathrm{~V} v s$ $\mathrm{Li}^{+} / \mathrm{Li}$ was reached, corresponding to the degradation of the electrolyte (pathway $\mathbf{A}$ ). In the case of $\mathrm{ZnOnw}$, the process is quite different. The increase in $\Delta \mathrm{E}_{\text {light/dark }}$ as presented in Figure $\mathbf{3 b}$ (i.e., black solid line) is much slower and $\Delta \mathrm{E}_{\text {light/dark }}$ reaches Elimit at a higher applied current of $3.5 \mu \mathrm{A}$. Moreover, the $\mathrm{FE}$ under illumination is improved with $\mathrm{ZnOnw}$ compared to $\mathrm{ZnOm}$ (i.e., 75 and 40 $\%$, respectively, at $\mathrm{I}=1.5 \mu \mathrm{A}$ ). This gain seems also stabilized for applied current greater than 2 $\mu \mathrm{A}$. These results show that, depending on the nature of $\mathrm{ZnO}$ (i.e., $\mathrm{ZnOm}$ or $\mathrm{ZnOnw}$ ), the electrolyte oxidation cannot be considered as negligible under illumination.

The comparison of the $\mathrm{ZnO}$ forms shows that $\mathrm{ZnOnw}$ exhibits more interesting results regarding the faradaic efficiency. Supported by previous results, one can suggest that, these different FE values are correlated to the strong difference in terms of morphology leading, for $\mathrm{ZnOnw}$, to a high developed surface composed of nonpolar $m$-planes as well as by its much higher electrical conductivity. ${ }^{32}$

(a)

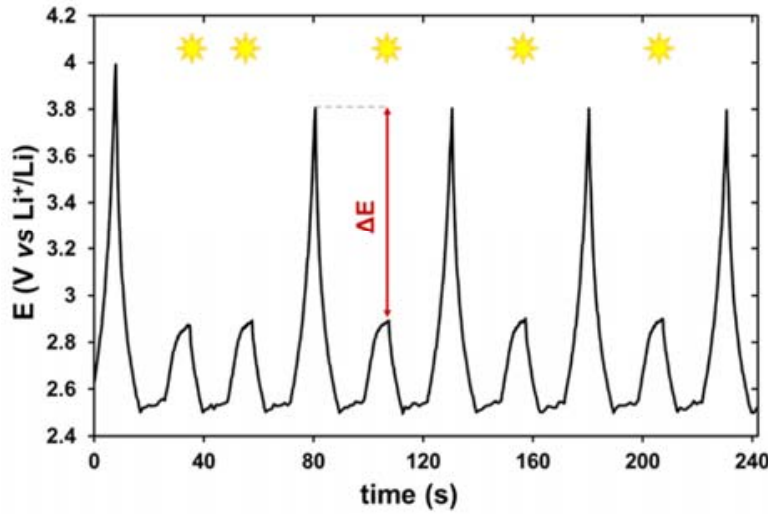

(b)

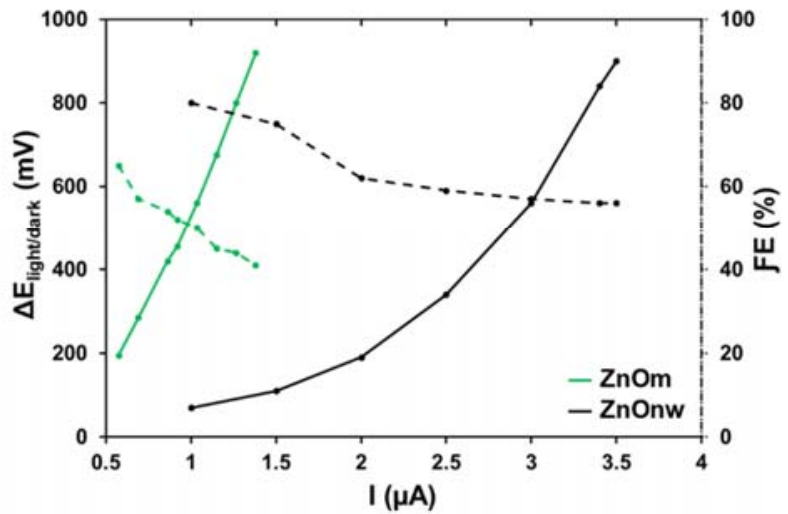

Figure 3.(a) Galvanostatic curve of $\mathrm{ZnOnw}$ under dark and illumination, cycled at an applied current of $3.5 \mu \mathrm{A}$. (b) Evolution of the $\Delta \mathrm{E}_{\text {light/dark }}$ (solid line) and $\mathrm{FE}$ (dashed line) as a function of the applied current for bare $\mathrm{ZnOm}$ (green curves) and $\mathrm{ZnOnw}$ (black curves). 


\section{Photo-electrochemical study with $\mathrm{ZnO} / \mathrm{Ru}^{\mathrm{II}}$ electrodes}

In order to enhance the efficiency of the electrodes without over expressed the photooxidation of the electrolyte, the $\left[\mathrm{Ru}(\mathrm{bpy})_{2}\left(\mathrm{bpyNH}_{2}\right)\right]^{2+}$ complex was used. This complex can act both as a redox storage unity and as a photosensitive element. With regard to the preliminary tests performed by grafting the $\mathrm{Ru}^{\mathrm{II}}$ complex on $\mathrm{In}_{2} \mathrm{O}_{3}: \mathrm{Sn}$ (ITO) surface under illumination, no potential changes are observed despite the interesting photoactive and redox properties of the $\mathrm{Ru}^{\mathrm{II}}$ complex. This is most likely due to a deactivation of excited states by energy transfer between molecules owing to their direct proximity as previously reported for BODIPY derivatives. ${ }^{6}$ In order to avoid this quenching process, $p$-anisidine (An) was used as a dilution agent. This molecule was chosen because i) the amino functional group para to the methoxy permits the same functionalization methodology as for the $\mathrm{Ru}^{\mathrm{II}}$ complex and ii) the molecule is not photoactive and electrochemically stable in the potential range explored. It should be noted that no specific UV-visible changes are observed when the electroreduction is carried out in the presence of An showing that this molecule acts only as a spacer and does not react with $\mathrm{Ru}^{\mathrm{II}}$ complex. Thereby, different ratios of $[\mathbf{A n}] /\left[\mathrm{Ru}^{\mathrm{II}}\right]$ ranging from 0 to 1 were electrodeposited on ITO surfaces. A good linearity between the absorbance of the $\mathrm{Ru}(\mathrm{II})$ complex (peak at $\lambda=465 \mathrm{~nm}$ ) and the ratio used was observed, as reported in Figure S3 (dashed line). This linearity highlights the same electrochemical reactivity of the diazonium issued from the $\mathrm{Ru}^{\mathrm{II}}$ complex and $\mathrm{An}$. Consequently, galvanostatic measurements under dark and illumination conditions were achieved and unambiguously show the presence of $\mathrm{Ru}^{\mathrm{II}}$ complex that leads to a decrease in $\Delta \mathrm{E}_{\text {light/dark }}$ as seen in Figure $\mathbf{S 3}$ (red line). In order to find the optimal conditions to reach the highest $\Delta$ Elight/dark, the amount of An was modulated. As a result, a 0.1 ratio of $[\mathbf{A n}] /\left[\mathrm{Ru}^{\mathrm{II}}\right]$ is efficient to avoid recombination process and to obtain a good $\Delta$ Elight/dark. 
Same results have been obtained with $\mathrm{ZnO} / \mathrm{Ru}^{\mathrm{II}}$, therefore this ratio was used in the presence of $\mathrm{ZnO}$ substrates.

Under illumination, an additional process can occur as described in Scheme 3.

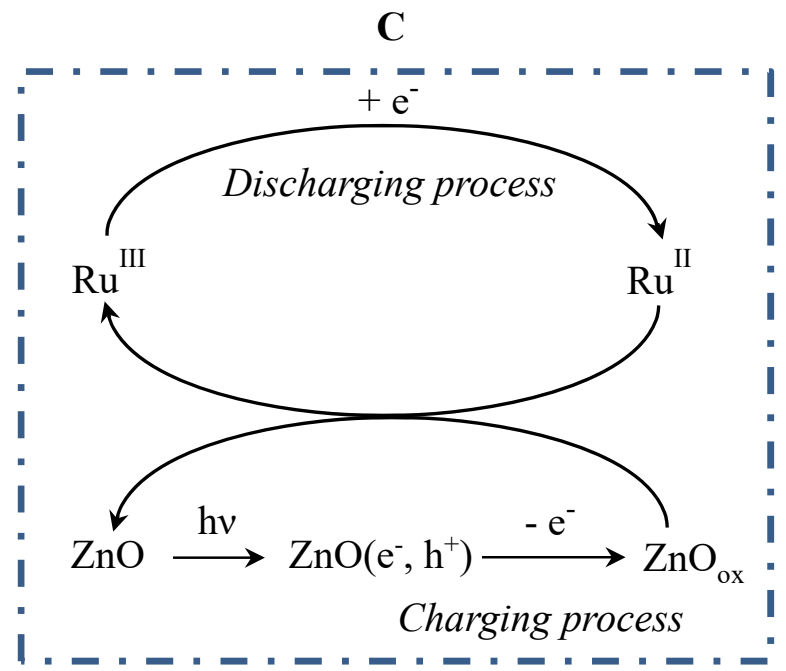

Scheme 3. Photo-electrochemical oxidation pathway involving $\mathrm{ZnO}$ and $\mathrm{Ru}^{\mathrm{II}}$ during the photo-charging process.

Under illumination, as previously mentioned, $\mathrm{ZnO}$ excited form $\left(\mathrm{ZnO}\left(\mathrm{e}^{-}, \mathrm{h}^{+}\right)\right)$is easily oxidizable, then the electrogenerated $\mathrm{ZnO}_{\mathrm{ox}}$ is involved into a redox process to restore $\mathrm{ZnO}$ while forming $\mathrm{Ru}^{\mathrm{III}}$ (pathway $\mathbf{C}$ ). In the discharging process under darkness, the initial $\mathrm{Ru}^{\mathrm{II}}$ can be regenerated by a cathodic process. This mechanism is exergonic taking into account the difference of the $\Delta \mathrm{E}^{\circ}$ of the two redox processes (around 1.4 V). ${ }^{16,21}$ Concerning the $\mathrm{ZnOm} / \mathrm{Ru}^{\mathrm{II}}$ electrodes, Figure 4 (i.e. black solid line) basically exhibits two successive phases, namely an increase in the $\Delta$ Elight/dark


This new feature is assigned to the main pathway $\mathbf{C}$ and permits to clearly highlight the role of $\mathrm{Ru}^{\mathrm{II}}$ complexes as a redox storage unity of $\mathrm{ZnOm}$. 


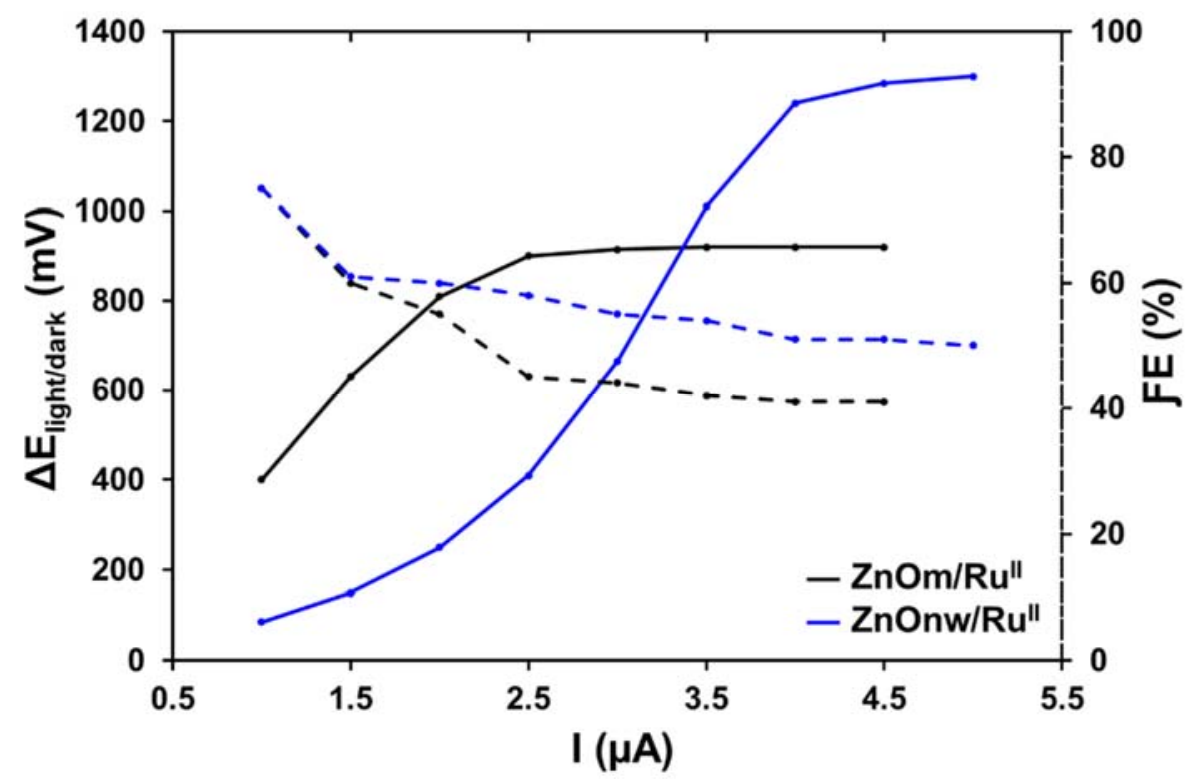

Figure 4. Evolution of the $\Delta \mathrm{E}_{\text {light/dark }}$ (solid line) and $\mathrm{FE}$ (dashed line) as a function of the applied current for $\mathrm{ZnOm} / \mathrm{Ru}^{\mathrm{II}}$ (black lines) and $\mathrm{ZnOnw} / \mathrm{Ru}^{\mathrm{II}}$ (blue lines) electrodes.

The same trend is revealed in the case of $\mathrm{ZnOnw} / \mathrm{Ru}^{\mathrm{II}}$ electrodes, but with a slower $\Delta \mathrm{E}_{\text {light/dark }}$ increase towards the plateau from $4.5 \mu \mathrm{A}$ and with a higher maximum $\Delta$ Elight/dark of $1.3 \mathrm{~V}$ (Figure 4 (blue), Table S1). As in the case of bare $\mathrm{ZnOnw}$, the moderate increase in $\Delta \mathrm{E}_{\text {light/dark }}$ is directly associated with the NW structural morphology and electrical conductivity. The significant $\Delta E_{\text {light/dark }}$ obtained can be explained by the thermodynamically favorable interaction between the $\mathrm{Ru}^{\mathrm{II}}$ complex and the $\mathrm{ZnOnw}$ substrate. Nevertheless, $\mathrm{Ru}^{\mathrm{II}}$ polypyridyl complexes are well-known for their good photo-activity and their long-lived singlet-to-triplet excited state. ${ }^{20,33}$ Consequently, the photo-activation of $\mathrm{ZnO}$ and $\mathrm{Ru}^{\mathrm{II}}$ would be both expected to allow a multistep photo-activated electrochemical process. In the case of $\left[\mathrm{Ru}(\mathrm{bpy})_{2}\left(\mathrm{bpyNH}_{2}\right)\right]^{2+}$ complex, a theoretical voltage gain of $2.1 \mathrm{~V}$ can be obtained under illumination. ${ }^{21}$ This behavior can be eventually related to both the redox storage unity activity and the photo-assisted effect of $\mathrm{Ru}^{\mathrm{II}}$ during the charging. The galvanostatic measurements of the best activity with a maximum $\Delta$ Elight/dark of $1.3 \mathrm{~V} v s \mathrm{Li}^{+} / \mathrm{Li}$ is 
shown in Figure 5. The present photo-induced voltage gain of $1.3 \mathrm{~V}$ represents the highest value reported in the literature, as compared to the values of 150 and $770 \mathrm{mV}$ reported. ${ }^{6,7}$ However, this is associated with a relatively low FE reaching a value of $50 \%$ in the best configuration. This relative low FE could be due to i) the less efficiency of the $\mathrm{ZnO}$ coverage using $\mathrm{Ru}^{\mathrm{II}}$ complex, by taking into account the fact that the $\mathrm{Ru}^{\mathrm{II}}$ complex exhibits only one $\mathrm{NH}_{2}$ function (as compared to two functions for the $\mathrm{Fe}^{\mathrm{II}}$ complex) allowing $\mathrm{ZnO}\left(\mathrm{e}^{-}, \mathrm{h}^{+}\right)$to react with the electrolyte, and to ii) the eventual contribution of the electrolyte oxidation with $\mathrm{Ru}^{\mathrm{III}}$, since the $\mathrm{E}_{1 / 2} \mathrm{Ru}^{\mathrm{II}} / \mathrm{Ru}^{\mathrm{III}}(4.14 \mathrm{~V} v s$ $\left.\mathrm{Li}^{+} / \mathrm{Li}\right)$ is relatively close to the stability limit of the electrolyte.



Figure 5. Galvanostatic curve of the $\mathrm{ZnOnw} / \mathrm{Ru}^{\mathrm{II}}$ electrodes under dark and illumination, cycled at an applied current of $5 \mu \mathrm{A}$.

The $\mathrm{Ru}^{\mathrm{II}}$ complex did not exhibit high FE, which is presumably due to inefficient coverage of the $\mathrm{ZnO}$ surface. In this context, we pursue the study involving $\mathrm{Fe}^{\mathrm{II}}$ polypyridine complex which exhibits two $\mathrm{NH}_{2}$ moieties. We expect that this functionalization helps to better mask the extreme 
reactivity of the excited form of $\mathrm{ZnO}$. In addition, it is non light sensitive whereas its lower $\mathrm{E}_{1 / 2}$ value (i.e. $\left.3.9 \mathrm{~V} v s \mathrm{Li}^{+} / \mathrm{Li}\right)$ is in a better accordance with the electrolyte stability.

\section{Photo-electrochemical study with $\mathrm{ZnO} / \mathrm{Fe}^{\mathrm{II}}$ electrodes}

The $\left[\mathrm{Fe}\left(\text { tpy- }-\mathrm{NH}_{2}\right)_{2}\right]^{2+}$ complex was grafted in the same conditions of $\mathrm{Ru}^{\mathrm{II}}$, i.e. with a [Anisidine] $]\left[\mathrm{Fe}^{\mathrm{II}}\right]$ ratio equal to 0.1 . According to the reaction mechanism described in Scheme 4, a new process can occur under illumination.

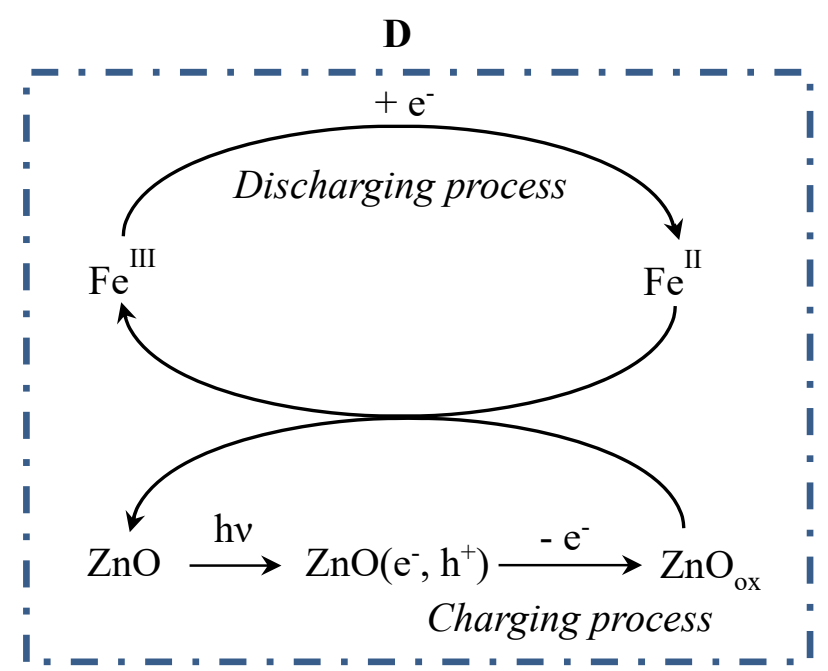

Scheme 4. Photo-electrochemical oxidation pathway involving $\mathrm{ZnO}$ and $\mathrm{Fe}^{\mathrm{II}}$ during the photo-charging process.

As in the case of $\mathrm{Ru}^{\mathrm{II}}$ complex, the illumination of $\mathrm{ZnO}$ in presence of $\mathrm{Fe}^{\mathrm{II}}$ species can lead to the oxidized Fe ${ }^{\mathrm{III}}$ species (pathway D). This overall mechanism during the charging process should be very efficient taking into account the large difference of the $\Delta \mathrm{E}^{\circ}$ of the two redox processes (around $1.6 \mathrm{~V}) .{ }^{16,19} \mathrm{In}$ the case of $\mathrm{ZnOm} / \mathrm{Fe}^{\mathrm{II}}$ electrodes, $\Delta$ Elight/dark voltage starts around $205 \mathrm{mV}$ (at $1 \mu \mathrm{A}$ ) and then increases until reaching a plateau around $690 \mathrm{mV}$. Beyond an applied current of $4.5 \mu \mathrm{A}$, a slow decrease in $\Delta \mathrm{E}_{\text {light/dark }}$ occurs until Elimit is reached as seen in Figure 6 (i.e., black solid line). This behavior can be explained by the fact that, under $3 \mu \mathrm{A}$, the applied current density is too low to reach the full potential of the $\mathrm{Fe}^{\mathrm{II}}$ complex. This trend is very similar to that of 
$\mathrm{ZnOm} / \mathrm{Ru}^{\mathrm{II}}$ electrodes and is consequently attributed to the predominant pathway $\mathbf{D}$ instead of pathway B (Scheme 2) to clearly demonstrate the role of $\mathrm{Fe}^{\mathrm{II}}$ complexes as a redox storage unity of $\mathrm{ZnOm}$. Although the maximum $\Delta \mathrm{E}_{\text {light/dark }}$ is higher with bare $\mathrm{ZnOm}(920 \mathrm{mV})$, Elimit is reached at a really higher applied current of $5.5 \mu \mathrm{A}$ for $\mathrm{ZnOm} / \mathrm{Fe}^{\mathrm{II}}$ electrodes as compared to $1.5 \mu \mathrm{A}$ for $\mathrm{ZnOm}$. As regards to the $\mathrm{FE}$ evolution under illumination and in dark as seen in Figure 6 and summarized in Table S2, a lower electrolyte oxidation contribution is obtained in presence of $\mathrm{Fe}^{\mathrm{II}}$ complexes. For example, at their respective Elimit, the $\mathrm{FE}$ of $\mathrm{ZnOm} / \mathrm{Fe}^{\mathrm{II}}$ is $72 \%$ compared to only $40 \%$ for ZnOm (Table S2).

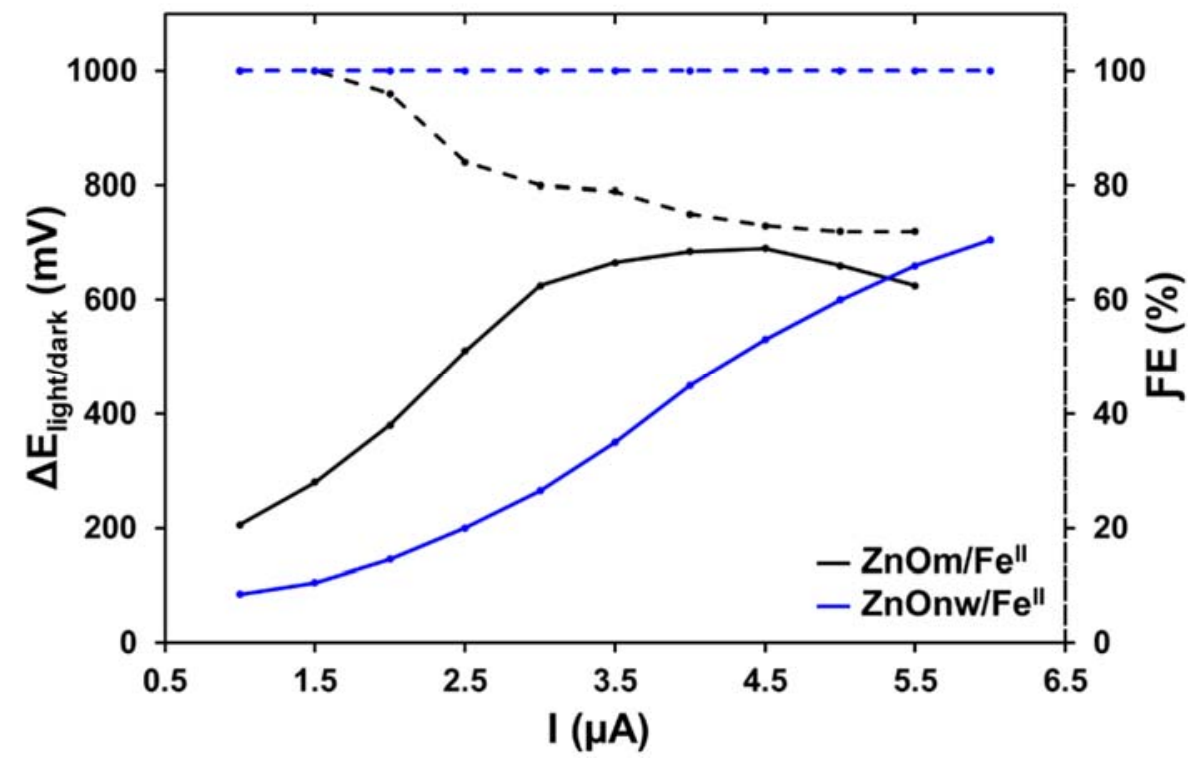

Figure 6. Evolution of the $\Delta \mathrm{E}_{\text {light/dark }}$ (solid line) and $\mathrm{FE}$ (dashed line) as a function of the applied current for $\mathrm{ZnOm} / \mathrm{Fe}^{\mathrm{II}}$ (black curves) and $\mathrm{ZnOnw} / \mathrm{Fe}^{\mathrm{II}}$ (blue curves) electrodes.

In the case of $\mathrm{ZnOnw} / \mathrm{Fe}^{\mathrm{II}}$ electrode as shown in Figure 6 (i.e. blue solid line), the increase in $\Delta$ Elight/dark for $\mathrm{ZnOnw} / \mathrm{Fe}^{\mathrm{II}}$ electrodes is much slower than for $\mathrm{ZnOm} / \mathrm{Fe}^{\mathrm{II}}$ electrodes but it can reach almost the same value (660 vs $705 \mathrm{mV}$, respectively at Elimit) with a higher applied current (5 $\mu \mathrm{A}$ vs $6 \mu \mathrm{A}$, respectively). A very stable and high $\mathrm{FE}$ value of $100 \%$ is reached for $\mathrm{ZnOnw} / \mathrm{Fe}^{\mathrm{II}}$ electrodes regardless of the applied current, which can be explained by the better surface coverage 
of the complex on top of $\mathrm{ZnO} \mathrm{NWs}$ lowering the contribution of side reaction and presumably improving the kinetic of the electron transfer between electro-photo induced $\mathrm{ZnO}_{\text {ox }}$ and $\mathrm{Fe}^{\mathrm{II}}$ to form, in a very high yield, $\mathrm{Fe}^{\mathrm{III}}$. Consequently, beside its storage activity, the complex acts as an electrolyte barrier. This interesting result unambiguously shows that we can benefit from the electro-photochemical properties of $\mathrm{ZnO}$ to produce $\mathrm{Fe}^{\mathrm{III}}$ at a reduced cost with a high overall efficiency

\section{CONCLUSION.}

In summary, we report a proof-of-concept of two different $\mathrm{ZnO}$ morphology electrodes ( $\mathrm{ZnOm}$ and $\mathrm{ZnOnw}$ ) acting as a light inducer for electrochemical energy storage. The efficiency of the electrodes can be easily tuned by the nature of the unit storage grafted onto the $\mathrm{ZnO}$ substrate, depending on the nature of the transition metal ( $\mathrm{Ru}$ or $\mathrm{Fe})$ and the coverage of the surface. The type of the $\mathrm{ZnO}$ scaffold combined with the nature of the complex also impact the capability of the system. Experiments have demonstrated that, according to their higher electrical conductivity, $\mathrm{ZnO}$ NWs show the best results. When operated galvanostatically, similarly to classical battery charge/discharge processes, $\mathrm{ZnOnw} / \mathrm{Ru}^{\mathrm{II}}$ electrode shows a huge gain of $1.3 \mathrm{~V}$ under illumination while reaching a faradaic efficiency of $50 \%$. This is the highest gain of voltage never attained in this kind of system. In addition, and considering the results obtain with $\mathrm{Fe}^{\mathrm{II}}$, we can suppose that the faradaic efficiency can be improved by a better coverage of the $\mathrm{Ru}^{\mathrm{II}}$ complex into $\mathrm{ZnO}$ surface. In the case of $\mathrm{ZnOnw} / \mathrm{Fe}^{\mathrm{II}}$ electrode, a significant gain of $705 \mathrm{mV}$ is observed, but in contrary to $\mathrm{ZnOnw} / \mathrm{Ru}^{\mathrm{II}}$ electrode, a faradaic efficiency of $100 \%$ is obtained. This is the first study which permits a light assisted charge of a $\mathrm{ZnOnw}$ modified electrode with an important gain in voltage and a faradaic efficiency of $100 \%$, which implies a lack of damages to the electrolyte. These results show promising photo-assisted rechargeable systems based on $\mathrm{ZnO}$ NWs substrates that allow the restitution of a higher electrical energy than that consumed during the charge process 
with an interesting way to tune both the gain in voltage and the faradaic efficiency in function of the transition complex used.

\section{EXPERIMENTAL METHODS.}

\section{Synthesis of $\mathbf{R u}(\mathrm{II})$ complex}

$\left[\mathrm{Ru}(\mathrm{bpy})_{2}\left(\mathrm{bpyNH}_{2}\right)\right]\left(\mathrm{PF}_{6}\right)_{2}$ is prepared following literature procedures. ${ }^{21}$

\section{Synthesis of Fe(II) complex}

$\left[\mathrm{Fe}\left(\text { tpy- } \mathrm{NH}_{2}\right)_{2}\right]\left(\mathrm{PF}_{6}\right)_{2}$ is prepared following literature procedures. ${ }^{34}$

\section{Synthesis of $\mathrm{ZnO}$}

ZnOm were grown on ITO/glass substrates by dip coating using a sol-gel process. $375 \mathrm{mM}$ of zinc acetate dihydrate and $375 \mathrm{mM}$ of monoethanolamine were mixed in pure ethanol solvent. The resulting solution was stirred for a couple of hours at $60{ }^{\circ} \mathrm{C}$ on a hot plate and then at room temperature to form the sol. The withdrawal speed was fixed to $3.3 \mathrm{~mm} / \mathrm{s}$. Post-deposition annealing at $300{ }^{\circ} \mathrm{C}$ and $500{ }^{\circ} \mathrm{C}$ in air was achieved for evaporating the residual organic compounds and for crystallizing the $\mathrm{ZnOm}$, respectively. ${ }^{35} \mathrm{ZnOnw}$ were grown on top of the ITO/glass/ZnOm substrates by $\mathrm{CBD}$ using $30 \mathrm{mM}$ of zinc nitrate hexahydrate and $30 \mathrm{mM}$ of hexamethylenetetramine mixed in aqueous solution (Figure S4) ${ }^{29}$

\section{Electrode modification}

The electrodeposition experiments were performed under argon atmosphere in a three-electrode cell using a platinum wire as counter electrode. Potentials were referred to an $\mathrm{Ag} / \mathrm{AgNO}_{3} 0.01 \mathrm{M}$ reference electrode in $\mathrm{CH}_{3} \mathrm{CN}+0.01 \mathrm{M}$ TBAP. The working electrodes were ITO, $\mathrm{ZnOm}$ and ZnOnw. Experiments were carried out in an argon filled glove box at room temperature in a 
solution of $0.6 \mathrm{mM}$ of complex in $\mathrm{CH}_{3} \mathrm{CN}+0.1 \mathrm{M}$ TBAP and 1.5 equivalent of isoamyl nitrite. Electrografting experiments were performed using cyclic voltammetry on conductive surface and consist in different potential cycles between $1.1 \mathrm{~V}$ and $-1 \mathrm{~V} v s \mathrm{Ag}^{+} / \mathrm{Ag}$ at a scan rate of $100 \mathrm{mV} . \mathrm{s}^{-}$ ${ }^{1}$. Potentials can be converted to $\mathrm{Li} / \mathrm{Li}^{+}$scale by adding $3.58 \mathrm{~V}$ or to NHE reference electrode by adding $540 \mathrm{mV} \cdot{ }^{36,37}$ Fifty cycles of electrodeposition were performed on the two complexes with a $[\mathrm{An}] /[\mathrm{Ru}(\mathrm{II})]$ ratio of 0.1 onto $\mathrm{ZnO}$ surfaces. The electrochemical data were recorded using a VSP-300 potentiostat from Biologic.

\section{Scanning electron microscopy}

Top-view and cross-sectional view field-emission gun scanning electron microscopy images (FEG-SEM) were collected using a FEI Quanta 250 FEG-SEM.

\section{Spectroscopy instruments:}

UV-Visible absorption measurements were carried out on a Shimadzu UV-2501 PC spectrophotometer with ITO as reference.

\section{Raman spectroscopy}

The Raman spectra were recorded using a Renishaw in Via Raman system. The detector was a Peltier-cooled charge coupled device camera (CCD) and the spectra resolution was about $1 \mathrm{~cm}^{-1}$. Two different excitation wavelengths, the $532 \mathrm{~nm}$ for $\left(\left[\mathrm{Fe}\left(\operatorname{tpy}-\mathrm{NH}_{2}\right)_{2}\right]^{2+}, \mathrm{ZnOnw} / \mathrm{Fe}^{\mathrm{II}}\right.$ and $\mathrm{ZnOnw} / \mathrm{Ru}^{\mathrm{II}}$ electrodes $)$ and $785 \mathrm{~nm}\left(\left[\mathrm{Ru}(\mathrm{bpy})_{2}\left(\mathrm{bpyNH}_{2}\right)\right]^{2+}\right)$ lines of a $\mathrm{Nd}: \mathrm{YAG}$ and a diode laser respectively, were used to get photoluminescence-free signals. The measurements were performed with an X50 (NA=0.9) objective. The line mode of the spectrometer was used to decrease the power density at the sample and to get averaged data. The line length was about $60 \mu \mathrm{m}$. Before each analysis, the output laser power was adjusted to avoid excessive heating of the sample. For 
this, the main criterion was to select a power density for which no evolution of the line shape of the spectra versus time was detectable. Typical power densities used were below $20 \mu \mathrm{W} / \mu \mathrm{m}^{2}$.

\section{Electrochemical and photo-electrochemical measurements:}

The electrochemical experiments were performed under argon atmosphere in a three-electrode cell using metallic lithium foil (Sigma-Aldrich) as reference and counter electrode, and $\mathrm{ZnO}$ surfaces (modified or not) as working electrode (Figure S5). The chosen electrode of around $0.3 \mathrm{~cm}^{2}$ surfaces is immersed in a solution of $1 \mathrm{M}$ of Lithium bis(trifluoromethanesulfonyl)imide (LiTFSI) in Ethylene Carbonate:Dimethyl Carbonate (EC:DMC 1:1 vol.\%). The electrochemical data were recorded using a VSP-300 potentiostat from Biologic. A LAX 1450 Xe-lamp (Muller-Elektronik, Germany) was used as the light source, Ir and UV from $200 \mathrm{~nm}$ were cut off by a quartz flask containing water. To avoid overheating, the powerfull of the lamp was reduced by introducing a filter (Abs $=0.1$ at $\lambda=400 \mathrm{~nm})$ between the lamp and the electrochemical cell. The OCV and galvanostatic charge/discharge measurements were conducted with fixed potential limits between $2.5 \mathrm{~V}$ and $4.2 \mathrm{~V} v s . \mathrm{Li}^{+} / \mathrm{Li}$. Only the charge is subject to the changing of light (in the dark or under illumination). Each experiment was made in the same conditions: a time of charge and discharge of nine seconds was imposed with a relaxation time of nine seconds between each cycle. Different applied current was tested ranging from 1 to $5.5 \mu \mathrm{A}$. Faradaic efficiency (FE in \%) was measured by dividing the time of discharge by the time of charge.

\section{ASSOCIATED CONTENT}

\section{Supporting Information}

Additional figures and tables. Details on the synthesis of the complexes 
This material is available free of charge on http://pubs.acs.org.

\section{AUTHOR INFORMATION}

\section{Corresponding Author}

* E-mail: Jean-Claude.Lepretre@lepmi.grenoble-inp.fr

\section{Notes}

The authors declare no competing financial interest.

\section{ACKNOWLEDGMENT}

The authors are grateful for financial support from Labex CEMAM under the contract ANR-10LABX-44-01 through the project EARTH.

\section{REFERENCES}

(1) Schmidt, D.; Hager, M. D.; Schubert, U. S. Photo-Rechargeable Electric Energy Storage Systems. Adv. Energy Mater. 2016, 6 (1), 1500369.

(2) Yu, M.; McCulloch, W. D.; Huang, Z.; Trang, B. B.; Lu, J.; Amine, K.; Wu, Y. SolarPowered Electrochemical Energy Storage: An Alternative to Solar Fuels. J. Mater. Chem. A 2016, 4 (8), 2766-2782.

(3) Li, M.; Lu, J.; Chen, Z.; Amine, K. 30 Years of Lithium-Ion Batteries. Adv. Mater. 2018, 30 (33), 1800561.

(4) Li, Q.; Liu, Y.; Guo, S.; Zhou, H. Solar Energy Storage in the Rechargeable Batteries. Nano Today 2017, 16, 46-60.

(5) Oyaizu, K.; Niibori, Y.; Takahashi, A.; Nishide, H. BODIPY-Sensitized Photocharging of 
Anthraquinone-Populated Polymer Layers for Organic Photorechargeable Air Battery. $J$. Inorg. Organomet. Polym. Mater. 2013, 23 (1), 243-250.

(6) Godet-Bar, T.; Leprêtre, J.-C.; Poizot, P.; Massuyeau, F.; Faulques, E.; Christen, A.; Minassian, F.; Poisson, J.-F.; Loiseau, F.; Lafolet, F. Light Assisted Rechargeable Batteries: A Proof of Concept with BODIPY Derivatives Acting as a Combined Photosensitizer and Electrical Storage Unit. J. Mater. Chem. A 2017, 5 (5), 1902-1905.

(7) Paolella, A.; Faure, C.; Bertoni, G.; Marras, S.; Guerfi, A.; Darwiche, A.; Hovington, P.; Commarieu, B.; Wang, Z.; Prato, M.; et al. Light-Assisted Delithiation of Lithium Iron Phosphate Nanocrystals towards Photo-Rechargeable Lithium Ion Batteries. Nat. Commun. 2017, $8,14643$.

(8) Law, M.; Goldberger, J.; Yang, P. Semiconductor Nanowires and Nanotubes. Annu. Rev. Mater. Res. 2004, 34 (1), 83-122.

(9) Lieber, C. M.; Wang, Z. L. Functional Nanowires. MRS Bull. 2007, 32 (02), 99-108.

(10) Garnett, E.; Yang, P. Light Trapping in Silicon Nanowire Solar Cells. Nano Lett. 2010, 10 (3), 1082-1087.

(11) Michallon, J.; Bucci, D.; Morand, A.; Zanuccoli, M.; Consonni, V.; Kaminski-Cachopo, A. Light Trapping in ZnO Nanowire Arrays Covered with an Absorbing Shell for Solar Cells. Opt. Express 2014, 22 (S4), A1174.

(12) Garnett, E. C.; Brongersma, M. L.; Cui, Y.; McGehee, M. D. Nanowire Solar Cells. Annu. Rev. Mater. Res. 2011, 41 (1), 269-295. 
(13) Özgür, Ü.; Alivov, Y. I.; Liu, C.; Teke, A.; Reshchikov, M. A.; Doğan, S.; Avrutin, V.; Cho, S.-J.; Morkoç, H. A Comprehensive Review of ZnO Materials and Devices. J. Appl. Phys. 2005, 98 (4), 041301.

(14) Schmidt-Mende, L.; MacManus-Driscoll, J. L. ZnO - Nanostructures, Defects, and Devices. Mater. Today 2007, 10 (5), 40-48.

(15) Xu, S.; Wang, Z. L. One-Dimensional ZnO Nanostructures: Solution Growth and Functional Properties. Nano Res. 2011, 4 (11), 1013-1098.

(16) Zoski, C. G. Handbook of Electrochemistry; Elsevier, 2007.

(17) Bustos-Torres, K. A.; Vazquez-Rodriguez, S.; la Cruz, A. M.; Sepulveda-Guzman, S.; Benavides, R.; Lopez-Gonzalez, R.; Torres-Martínez, L. M. Influence of the Morphology of $\mathrm{ZnO}$ Nanomaterials on Photooxidation of Polypropylene/ZnO Composites. Mater. Sci. Semicond. Process. 2017, 68 (May), 217-225.

(18) $\mathrm{Xu}, \mathrm{K}$. Electrolytes and Interphases in Li-Ion Batteries and Beyond. Chem. Rev. 2014, 114 (23), 11503-11618.

(19) Chiericato, G.; Silva, A. P. S. Spectroelectrochemistry and Investigation of Charge Transport Mechanisms of Iron Poly(Pyridyl) Redox Polymers. Polyhedron 2008, 27 (7), $1860-1866$.

(20) Prier, C. K.; Rankic, D. A.; MacMillan, D. W. C. Visible Light Photoredox Catalysis with Transition Metal Complexes: Applications in Organic Synthesis. Chem. Rev. 2013, 113 (7), $5322-5363$. 
(21) Jousselme, B.; Bidan, G.; Billon, M.; Goyer, C.; Kervella, Y.; Guillerez, S.; Hamad, E. A.; Goze-Bac, C.; Mevellec, J.-Y.; Lefrant, S. One-Step Electrochemical Modification of Carbon Nanotubes by Ruthenium Complexes via New Diazonium Salts. J. Electroanal. Chem. 2008, 621 (2), 277-285.

(22) Nguyen, V. Q.; Sun, X.; Lafolet, F.; Audibert, J.-F.; Miomandre, F.; Lemercier, G.; Loiseau, F.; Lacroix, J.-C. Unprecedented Self-Organized Monolayer of a Ru(II) Complex by Diazonium Electroreduction. J. Am. Chem. Soc. 2016, 138 (30), 9381-9384.

(23) Agnès, C.; Arnault, J.-C.; Omnès, F.; Jousselme, B.; Billon, M.; Bidan, G.; Mailley, P. XPS Study of Ruthenium Tris-Bipyridine Electrografted from Diazonium Salt Derivative on Microcrystalline Boron Doped Diamond. Phys. Chem. Chem. Phys. 2009, 11 (48), 11647.

(24) Tefashe, U. M.; Nguyen, Q. Van; Lafolet, F.; Lacroix, J.-C.; McCreery, R. L. Robust Bipolar Light Emission and Charge Transport in Symmetric Molecular Junctions. J. Am. Chem. Soc. 2017, 139 (22), 7436-7439.

(25) Van Nguyen, Q.; Lafolet, F.; Martin, P.; Lacroix, J. C. Ultrathin Molecular Layer Junctions Based on Cyclometalated Ruthenium Complexes. J. Phys. Chem. C 2018, 122 (50), 2906929074.

(26) Basu, A.; Gafney, H. D.; Strekas, T. C. Resonance Raman Spectra of Ruthenium(II) Complexes of Bipyridine and Substituted Bipyridines: Ground- and Excited-State Properties. Inorg. Chem. 1982, 21 (6), 2231-2235.

(27) Heinze, K.; Hempel, K.; Tschierlei, S.; Schmitt, M.; Popp, J.; Rau, S. Resonance Raman Studies of Bis(Terpyridine)Ruthenium(II) Amino Acid Esters and Diesters. Eur. J. Inorg. 
Chem. 2009, 2009 (21), 3119-3126.

(28) Šloufová, I.; Vlčková, B.; Procházka, M.; Svoboda, J.; Vohlídal, J. Comparison of SERRS and RRS Excitation Profiles of [Fe(Tpy)2]2+ (Tpy = 2,2':6',2'’-Terpyridine) Supported by DFT Calculations: Effect of the Electrostatic Bonding to Chloride-Modified Ag Nanoparticles on Its Vibrational and Electronic Structure. J. Raman Spectrosc. 2014, 45 (5), $338-348$.

(29) Parize, R.; Garnier, J.; Chaix-Pluchery, O.; Verrier, C.; Appert, E.; Consonni, V. Effects of Hexamethylenetetramine on the Nucleation and Radial Growth of $\mathrm{ZnO}$ Nanowires by Chemical Bath Deposition. J. Phys. Chem. C 2016, 120 (9), 5242-5250.

(30) French, S. A.; Sokol, A. A.; Bromley, S. T.; Catlow, C. R. A.; Rogers, S. C.; Sherwood, P. Assignment of the Complex Vibrational Spectra of the Hydrogenated ZnO Polar Surfaces Using QM/MM Embedding. J. Chem. Phys. 2003, 118 (1), 317-320.

(31) Cossuet, T.; Resende, J.; Rapenne, L.; Chaix-Pluchery, O.; Jiménez, C.; Renou, G.; Pearson, A. J.; Hoye, R. L. Z.; Blanc-Pelissier, D.; Nguyen, N. D.; et al. ZnO/CuCrO 2 Core-Shell Nanowire Heterostructures for Self-Powered UV Photodetectors with Fast Response. $A d v$. Funct. Mater. 2018, 28 (43), 1803142.

(32) Cossuet, T.; Donatini, F.; Lord, A. M.; Appert, E.; Pernot, J.; Consonni, V. PolarityDependent High Electrical Conductivity of ZnO Nanorods and Its Relation to Hydrogen. $J$. Phys. Chem. C 2018, 122 (39), 22767-22775.

(33) Campagna, S.; Puntoriero, F.; Nastasi, F.; Bergamini, G.; Balzani, V. Photochemistry and Photophysics of Coordination Compounds I; Balzani, V., Campagna, S., Eds.; Topics in 
Current Chemistry; Springer Berlin Heidelberg: Berlin, Heidelberg, 2007; Vol. 280.

(34) Mondal, P. C.; Singh, V.; Manna, A. K.; Zharnikov, M. Covalently Assembled Monolayers of Homo- and Heteroleptic Fe II -Terpyridyl Complexes on SiO x and ITO-Coated Glass Substrates: An Experimental and Theoretical Study. ChemPhysChem 2017, 18 (23), 34073415.

(35) Guillemin, S.; Appert, E.; Roussel, H.; Doisneau, B.; Parize, R.; Boudou, T.; Bremond, G.; Consonni, V. Controlling the Structural Properties of Single Step, Dip Coated ZnO Seed Layers for Growing Perfectly Aligned Nanowire Arrays. J. Phys. Chem. C 2015, 119 (37), 21694-21703.

(36) Pavlishchuk, V. V; Addison, A. W. Conversion Constants for Redox Potentials Measured versus Different Reference Electrodes in Acetonitrile Solutions at $25^{\circ} \mathrm{C}$. Inorganica Chim. Acta 2000, 298 (1), 97-102.

(37) Bard, A. J.; Faulkner, L. R. Electrochemical Methods: Fundamentals and Applications 2nd Edition; Wiley: New-York, 2001.

\section{TABLE OF CONTENT}

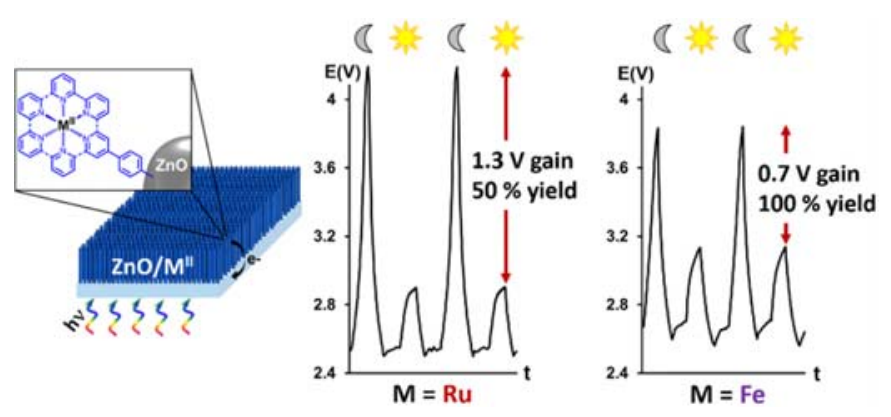

